\title{
PENGARUH KONDISI EKONOMI ORANG TUA TERHADAP MOTIVASI BELAJAR PADA SISWA SEKOLAH DASAR
}

\author{
Heldie Bramantha ${ }^{1}$ dan Dodik Eko Yulianto ${ }^{1}$ \\ ${ }^{\text {I}}$ Prodi Pendidikan Guru Sekolah Dasar, FKIP, Universitas Abdurachman Saleh Situbondo \\ heldiebramantha86@gmail.com
}

Naskah diterima: 9 September, 2019, direvisi: 20 Maret, 2020, diterbitkan: 31 Maret, 2020

\begin{abstract}
This study aims to determine the effect of economic conditions of parents on students' motivation in SD Negeri 3 Mangaran, Mangaran District, Situbondo Regency. This research is a quantitative research with ex post facto research. The population of this study were all students of SD Negeri 3 Mangaran, Mangaran Subdistrict, Situbondo Regency and the sample in this study amounted to 22 students. The data collection method uses a questionnaire to measure each variable of parents' economic conditions and learning motivation. Data analysis techniques use regression analysis. The results showed that the level of economic condition of parents was high by 40.9\% with respondents 9 students, moderate by $50 \%$ with respondents 11 students, and low by $9.1 \%$ with respondents 2 students. The influence of parents' economic conditions on learning motivation contributed $59.7 \%$ with $t=5.447$ and a significance value of 0.000 , while a contribution of $40.3 \%$ was influenced by other variables outside this study. From the results of the study it can be concluded that there is a positive influence between the Economic Conditions of Parents on the learning motivation of students at SD Negeri 3 Mangaran, Mangaran District, Situbondo Regency.
\end{abstract}

Keywords: Economic Condition of Parents; Motivation to learn.

\begin{abstract}
ABSTRAK
Penelitian ini bertujuan untuk mengetahui pengaruh kondisi ekonomi orang tua terhadap motivasi belajar siswa SD Negeri 3 Mangaran Kecamatan Mangaran Kabupaten Situbondo. Penelitian ini merupakan penelitian kuantitatif dengan jenis penelitian expost facto. Populasi dari penelitian ini yaitu seluruh siswa SD Negeri 3 Mangaran Kecamatan Mangaran Kabupaten Situbondo dan Sampel pada penelitian ini berjumlah 22 siswa. Metode pengumpulan data menggunakan angket untuk mengukur masing-masing variabel kondisi ekonomi orang tua dan motivasi belajar.Teknik analisis data menggunakan analisis regresi. Hasil penelitian menunjukkan bahwa tingkat kondisi ekonomi orang tua tinggi sebesar 40,9\% dengan responden 9 siswa, sedang sebesar 50\% dengan responden 11 siswa, dan rendah sebesar 9,1\% dengan responden 2 siswa. Pengaruh Kondisi Ekonomi Orang Tua terhadap motivasi belajar memberikan sumbangan sebesar 59,7 \% dengan $\mathrm{t}=$ 5,447 dan nilai signifikansi 0,000, sedangkan sumbangan sebesar 40,3\% dipengaruhi variabel lain di luar penelitian ini. Dari hasil penelitian dapat disimpulkan bahwa terdapat pengaruh yang positif antara Kondisi Ekonomi Orang Tua terhadap motivasi belajar siswa SD Negeri 3 Mangaran Kecamatan Mangaran Kabupaten Situbondo.
\end{abstract}

Kata Kunci: Keadaan Ekonomi Orang Tua; Motivasi Belajar.

\section{PENDAHULUAN}

Pendidikan merupakan salah satu cara untuk meningkatkan kualitas sumber daya manusia. Dengan tujuan mempersiapkan generasi muda sebagai penerus bangsa yang mampu menghadapiperkembangan ilmu pengetahuan dan teknologi. Menurut pasal 1 Undangundang RI No. 20Tahun 2003 tentang Sistem Pendidikan Nasional, pendidikan adalah usaha sadar dan terencanauntuk mewujudkan suasana belajar dan proses pembelajaran agar 
peserta didik secara aktifmengembangkan potensi dirinya untuk memiliki kekuatan spiritual keagamaan, pengendaliandiri, kepribadian, kecerdasan, akhlak mulia, serta keterampilan yang diperlukan dirinya,masyarakat, bangsa dan negara.

Kondisi ekonomi orangtua dapat diartikan sebagai suatu keadaan sumber daya material (keuangan) orangtua untuk meningkatkan kesejahteraan hidup anak-anaknya dengan berbagai kegiatan. Kondisi ekonomi orangtua adalah kenyataan yang terlihat atau terasakan oleh indera manusia tentang keadaan orangtua dan kemampuan orangtua dalam memenuhi kebutuhannya. Untuk memenuhi sarana dan kelengkapan tersebut diperlukan dana. Masalah ketersediaan dana untuk melanjutkan sekolah berkaitan erat dengan kondisi ekonomi orang tua. Kondisi ekonomi orang tua merupakan salah satu faktor eksternal timbulnya motivasi melanjutkan pendidikan anak.

Menurut Winkel (2012: 69) mengatakan bahwa motivasi belajar yakni keseluruhan daya penggerak psikis di dalam diri siswa yang menimbulkan kegiatan belajar, menjamin kelangsungan kegiatan belajar dan memberikan arah pada kegiatan belajar itu demi mencapai suatu tujuan. Anak yang sudah memiliki motivasi belajar tentunya akan lebih giat belajar sedangkan anak yang belum memiliki motivasi belajar inilah yang mengalami gangguan dalam belajar. Ada beberapa faktor yang mempengaruhi motivasi belajar, faktorfaktor tersebut yaitu faktor yang berasal dari dalam tubuh anak tersebut (internal) dan faktor yang berasal dari luar (eksternal). Faktor internal meliputi faktor psikis, jasmaniah dan kematangan fisik anak. Faktor eksternal meliputi segala sesuatu yang berasal dari luar diri anak tersebut seperti lingkungan belajar dan partisipasi orang tua. Faktor-faktor tersebut saling berinteraksi dalam mempengaruhi motivasi belajar seorang anak.

Motivasi adalah daya upaya yang mendorong seseorang (baik dari dalam ataupun dari luar) melakukan sesuatu untuk mendapatkan tujuan yang diinginkan oleh orang tersebut. Banyak cara yang dapat digunakan sebagai upaya untuk meningkatkan motivasi, karena Motivasi merupakan suatu proses psikologis yang mencerminkan sikap. Sardiman (2007: 92-95) menjelaskan ada beberapa contoh dan cara untuk menumbuhkan motivasi dalam kegiatan belajar di sekolah. Beberapa bentuk dan cara motivasi tersebut meliputi: (1) memberi angka; (2) hadiah; (3) saingan atau kompetisi; (4) ego-involvement; (5) memberi ulangan; (6) mengetahui hasil; (7) pujian; (8) hukuman; (9) hasrat untuk belajar; (10) minat; (11) Tujuan yang diakui.

Motivasi belajar sangat di pengaruhi oleh lingkungan keluarga terutama kondisi sosial ekonomi orang tua yang bisa mendukung prestasi siswa dalam setiap mata pelajaran. Orang tua merupakan faktor yang menentukan bagi peserta didik memberikan motivasi kepada anaknya sehingga prestasi belajar dapat tercapai maksimal. Biasanya siswa yang kondisi sosial ekonominya tinggi memilki motivasi lebih dibandingkan dengan yang rendah mereka tercukupi dari fasilitas yang diberikan oleh orang tua sehingga siswa mampu mencapai prestasi belajar yang tinggi.

Kondisi sosial ekonomi orang tua di daerah pedesaan pada umumnya menengah ke bawah. Dengan demikian maka siswa SD di daerah pedesaan berkecenderungan memiliki motivasi prestasi belajar yang lebih rendah dibandingkan dengan siswa di daerah perkotaan terutama siswa yang orang tuanya berlatar belakang ekonomi menengah ke atas. Siswa yang orang tuanya berlatar belakang ekonomi rendah cenderung tidak mampu menyediakan fasilitas belajar seperti bahan-bahan bacaan, terutama internet di rumah, HP yang memudahkan akses sumber belajar, sehingga hal ini menyebabkan siswa yang bersangkutan kurang termotivasi dalam kegiatan pembelajaran. Rendahnya permasalahan kondisi sosial ekonomi orang tua peserta didik menentukan pemahamannya tentang motivasi belajar yang akan diperoleh peserta didik. 
Kondisi ekonomi orang tua dalam keluarga akan diwarnai oleh bagaimana interaksi sosial yang terjadi diantara anggota keluarga dan interaksi sosial dengan masyarakat sekitar. Dalam keluarga, interaksi sosial di dasarkan atas rasa kasih sayang dan tanggung jawab yang diwujudkan dengan memperhatikan orang lain, bekerja sama, gotong royong, dan saling menolong serta adanya rasa peduli terhadap masa depan anggota keluarga. Interaksi orangtua tehadap anak-anaknya biasanya juga dilandasi hal-hal tersebut diatas termasuk peduli terhadap masa depan pendidikan anaknya.

Kondisi ekonomi orang tua yang dimaksud disini adalah kondisi ekonomi orang tua yang ditinjau dari status atau kedudukan perekonomian keluarga baik dari segi penghasilan mata pencaharian seseorang dalam memenuhi kebutuhan keluarga dari individu yang bersangkutan. Kondisi ekonomi ini dapat diukur dengan mengetahui pekerjaan/profesi, bentuk rumah, wilayah tempat tinggal ataupun lingkungan, dan sumber pendapatan.

Pengaruh tingkat ekonomi orang tua terhadap motivasi belajar adalah salah satu faktor yang mempengaruhi hasil belajar yang berasal dari eksternal siswa, sehingga perlu adanya motivasi tersendiri kepada siswa tentang keadaan ekonomi orang tua terutama bagi siswa yang keadaan ekonomi orangnya tuanya rendah. Terkadang orang tua yang keadaan ekonominya rendah beranggapan bahwa sekolah bagi anaknya hanya agar anaknya bias membaca dan menulis sehingga tidak perlu anaknya pandai dan menyekolahkan putra dan putrinya sampai ke jenjang yang lebih tinggi karena nanti hanya akan meneruskan pekerjaan orang tuanya. Hal ini yang menyebabkan siswa yang keadaan ekonomi orang tuanya rendah bersekolah hanya dijadikan sebagai rutinitas. Dalam bersekolah mereka tidak mempunyai motivasi yang lebih karena bersekolah hanya agar mereka bisa membaca dan menulis.

Keadaan inilah yang membuat peneliti ingin meneliti pengaruh kondisi ekonomi orang tua terhadap motivasi belajar siswa, yang mana sesungguhnya pendidikan itu penting agar dapat meningkatkan taraf hidup. Oleh karena itu, bagi siswa yang tingkat ekonomi orang tua rendah, maka perlu diberikan motivasi.

Berdasarkan observasi di SD Negeri 3 Mangaran, informasi dari guru kelas 1 bahwa yang menjadi penghambat bagi siswa untuk meraih prestasi karena didasari dari berbagai macam latar belakang keadaan sosial ekonomi yang berbeda. Keragaman latar belakang keadaan sosial ekonomi tersebut dapat berpengaruh pula pada kemampuan prestasi lebih tepatnya pada motivasi belajar anak-anak, sehingga keadaan sosial ekonomi tersebut merupakan salah satu faktor yang menentukan keberhasilan pendidikan anak. Salah satu faktor yang akan peneliti teliti adalah faktor dari luar siswa yaitu faktor tingkat sosial ekonominya. Siswa SD Negeri 3 Mangaran memiliki aset rumah tangga yang kurang dalam menunjang pendidikannya, dalam taraf dan status yang berbeda-beda misalnya ada anak yang tinggal di rumah milik keluarganya sendiri, namun ada siswa yang menumpang di rumah milik saudaranya yang lain, ada anak yang hanya berjalan kaki untuk berangkat ke sekolah dan ada juga anak yang menggunakan sepeda motor sebagai alat transportasi ke sekolah. Berdasarkan uraian tersebut, dapat diketahui bahwa anak-anak bermotivasi rendah bukan berarti memiliki minat yang rendah, namun bisa disebabkan oleh berbagai faktor yaitu keadaan ekonomi siswa yang mengakibatkan mereka tidak dapat mengembangkan motivasi yang dimilikinya.

\section{METODOLOGI}

Penelitian ini merupakan penelitian kuantitatif dengan jenis penelitian expost facto. Jenis penelitian ini untuk mengkaji pengaruh kondisi ekonomi orang tua $(\mathrm{X})$ terhadap motivasi 
belajar (Y). Pola hubungan antar variabel dalam penelitian ini digambarkan dalam desain penelitian sebagai berikut:

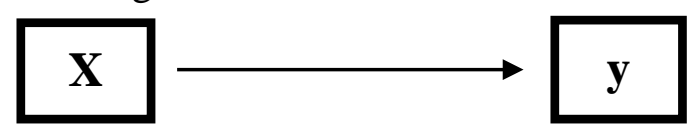

Keterangan : X: Pengaruh Kondisi Ekonomi Orang Tua Y: Motivasi Belajar

Populasi dalam penelitian ini adalah seluruh siswa kelas V SDN 3 Mangaran yang berjumlah 19 orang. Teknik pengambilan sampel menggunakan teknik sampel kluster (cluster sampling). Teknik sampel kluster adalah sebagian atau satu kelompok yang mewakili keseluruhan kelompok yang ada. Apabila subjeknya kurang dari 100 orang maka lebih baik diambil semua, sehingga penelitiannya merupakan penelitian populasi. Karena jumlah siswa kelas V kurang dari 100 orang, maka penulis menggunakan penelitian populasi seluruh siswa kelas V yang berjumlah 19 orang.

Prosedur dari penelitian ini adalah sebagai berikut: a) Tahap awal: peneliti melaksanakan observasi awal untuk identifikasi masalah dan analisis akar penyebab masalah di SD Negeri 3 Mangaran, menentukan subjek penelitian dan sampel yaitu SD Negeri 3 Mangaran Kabupaten Situbondo, menyusun instrumen penelitian. Instrumen yang digunakan berupa pedoman kuesioner (angket), memvalidasi instrumen penelitian. b) Tahap proses: penelitian ini dilaksanakan di SD Negeri 3 Mangaran Kabupaten Situbondo dengan menggunakan sampel siswa kelas 1 dengan membagikan kuesioner kepada siswa kelas 1. c) Tahap akhir: melakukan pembahasan dan menyimpulkan hasil penelitian secara deskriptif dari analisis data hasil kuesioner (angket) dan observasi.

Adapun teknik analis data yang dilakukan yaitu dengan menggunakan uji regresi linier. Rumusnya adalah sebagai berikut:

a. Uji Regresi Linier

Interpretasi terhadap persamaan juga relatif sama, sebagai ilustrasi, pengaruh kondisi ekonomi orang tua (X) terhadap motivasi belajar (Y) menghasilkan persamaan

$\mathrm{Y}=\mathrm{a}+\mathrm{b}(\mathrm{X})$

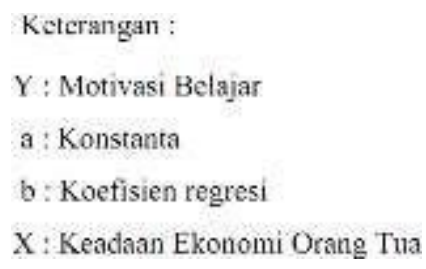

b. Analisis Korelasi Sederhana

Korelasi adalah hubungan antara satu variabel dengan variabel lain. Untuk mengetahui besarnya keeratan pengaruh dari variabel $\mathrm{X}$ terhadap variabel $\mathrm{Y}$, menggunakan rumus sebagai berikut:

$$
\mathrm{r}=\frac{\left(n \sum X Y\right)-\left(\sum X \sum Y\right)}{\sqrt{n \sum X^{2}-\left(\sum X\right)^{2}} \cdot \sqrt{n \sum Y^{2}-\left(\sum Y\right)^{2}}}
$$




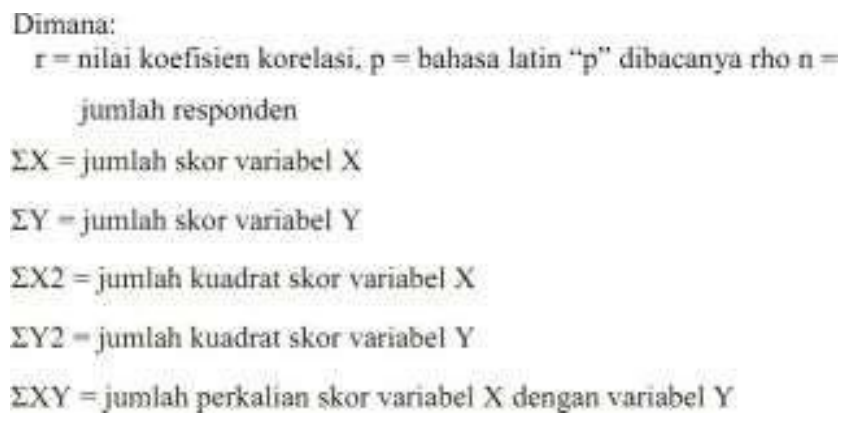

c. Koefisien Determinan (Penentu)

Selanjutnya untuk mencari besarnya nilai koefisien determinasi antara variabel bebas dan variabel tak bebas maka dapat digunakan rumus Koefisien Determinan (KD), dengan rumus umum :

$\mathrm{KD}=(\mathrm{r})^{2} \mathrm{x} 100 \%$

Keterangan $: r^{2}=$ nilai koefisien determinasi $=\% \mathrm{r}=$ nilai koefisien korelasi $=$ desimal

d. Uji Hipotesis

Sedangkan untuk membuktikan kebenaran dari hipotesis, maka dapat digunakan rumus sebagai berikut:

$$
\text { thitung }=r \frac{\overline{n-2}}{1-r^{2}}
$$

Bila $t_{\text {hitung }}$ lebih besar $t_{\text {table }}$ maka Ho ditolak atau Ha diterima Bila $\mathrm{t}_{\text {hitung }}$ lebih kecil $\mathrm{t}_{\text {table }}$ maka Ho diterima atau Ha ditolak.

Berikut di bawah ini merupakan validitas dan reabilitas instrument yang dilakukan dalam penelitian:

a. Uji Validitas (Uji Kesahihan) Angket

Validitas adalah suatu ukuran yang menunjukkan tingkat-tingkat kevaliditasan atau kesahihan suatu instrumen (Arikunto, 2011:64). Rumus korelasi yang dapat digunakan adalah yang dikemukakan oleh Pearson,yang dikenal dengan rumus Korelasi produc tmoment sebagai berikut:

$$
r_{x y}=\frac{N \sum X Y-\left(\sum X\right)\left(\sum Y\right)}{\sqrt{\left(N \sum X^{2}-\left(\sum X\right)^{2}\right)\left(N \sum Y^{2}-\left(\sum Y\right)^{2}\right)}}
$$

b. ReliabilitasAngket

Realibilitas dilakukan dengan rumus K-R 20. Rumus KR-20 $r_{1.1}=$

$$
\begin{aligned}
\text { Dengan } & \left(\frac{k}{k-1}\right)\left[\frac{v_{1}-\sum p q}{v_{1}^{2}}\right]- \\
r_{H} & =\text { reliabiliti.. } \\
K & =\text { banyaknya butir pertanyaan atau banyaknya soal } \\
\mathrm{v}_{1} & =\text { varians total } \\
P & =\text { proporsi responden yang menjawab betul }(1) \\
Q & =\text { proporsi responden yang menjawab salah }(0)
\end{aligned}
$$




\section{HASIL DAN DISKUSI}

Data mengenai kondisi ekonomi orang tuasiswa SD Negeri 3 Mangaran Kecamatan Mangaran Kabupaten Situbondopada penelitian ini terdapat tiga temuan yaitu tingkat kondisi ekonomi orang tua kreteria tinggi sebesar 40,9\% dengan banyak 9 siswa, untuk kreteria sedang sebesar 50\% dengan banyak siswa 11 siswa, dan kreteria rendah sebesar dengan banyak $9,1 \%$ dengan 2 siswa.

Data tentang kondisi ekonomi orang tua dalam penelitian ini diperoleh dengan skala yang dijawab oleh siswa SD Negeri 3 Mangaran. Berdasarkan Tabel 1maka dapat diketahui harga mean atau rata-rata skor sebesar 56,1, harga median atau nilai tengah sebesar 58, hargamode atau nilai yang paling sering muncul adalah 42 , standar deviasi sebesar 12,035, skor minimum adalah 36 dan skor maksimum adalah 77. Untuk skor setiap indikator dari kondisi ekonomi orang tua dapat dilihat pada tabel berikut ini.

a. Tabel Distribusi Frekuensi Kondisi Ekonomi Orang Tua

$\mathrm{K}=1+3,3 \log \mathrm{n}$

$\mathrm{N}=$ Jumlah responden yaitu 22

$\mathrm{K}=1+3,3 \log 22$

$\mathrm{K}=1+3,3 \times 1,342$

$\mathrm{K}=1+4,42$

$\mathrm{K}=5,42$

Sehingga jumlah kelas interval dibulatkan menjadi 5 kelas. Di bawah ini adalah tabel distribusi frekuensi untuk variabel kondisi ekonomi orang tua.

Tabel 1. Distribusi Frekuensi kondisi ekonomi orang tua

\begin{tabular}{|c|c|c|c|}
\hline No & Interval & Frekuensi & Presentase \% \\
\hline 1 & $36-44$ & 5 & 22,7 \\
\hline 2 & $45-53$ & 4 & 18,2 \\
\hline 3 & $54-62$ & 6 & 27,3 \\
\hline 4 & $63-71$ & 5 & 22,7 \\
\hline 5 & $72-80$ & 2 & 9,1 \\
\hline \multicolumn{2}{|r|}{} & 22 & 100 \\
\hline
\end{tabular}

Berdasarkan tabel di atas dapat diketahui distribusi frekuensi kondisi ekonomi orang tua tertinggi berada pada kelas interval nomor 3 yang mempunyai rentang 54-62 dengan jumlah sebanyak 6 siswa.

b. Grafik Distribusi Frekuensi Kondisi Ekonomi Orang Tua

Untuk visualisasi penyajian data tentang kondisi ekonomi orang tua digunakan grafik batang agar lebih menarik dan komunikatif. Grafik distribusi frekuensi untuk variabel kondisi ekonomi orang tua dapat dilihat di bawah ini. 


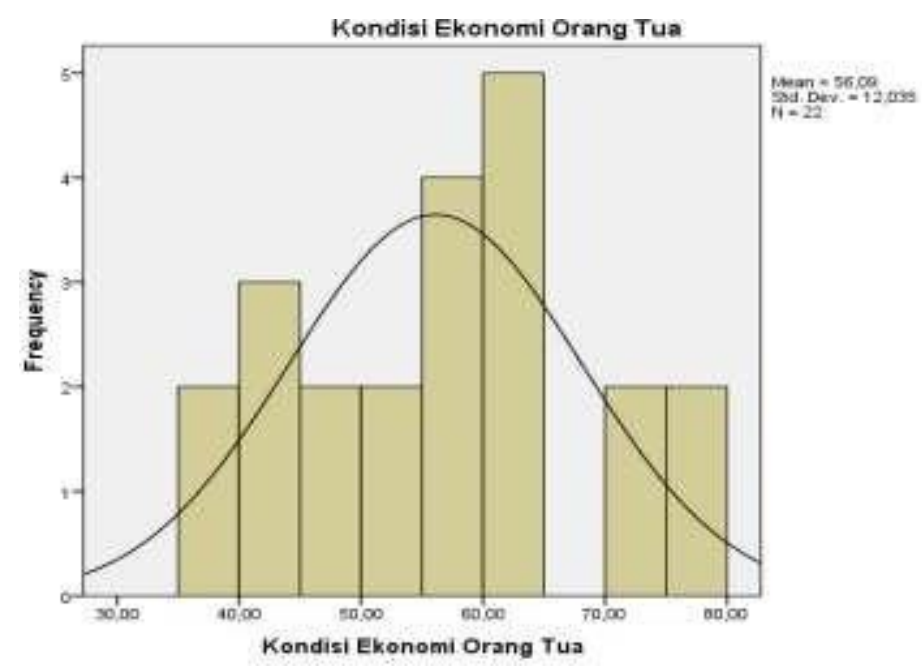

Gambar 1. Distribusi Frekuensi Kondisi Ekonomi Orang Tua

Distribusi data tentang kondisi ekonomi orang tua dapat dilihat pada Tabel 4 dan Gambar 1 yaitu rentang skor 36-44 sebanyak 5 siswa, rentang 45-53 sebanyak 4 siswa, rentang 54-62 sebanyak 6 siswa, rentang skor 63-71 sebanyak 5 siswa, dan rentang 72-80 sebanyak 2 siswa.

Data mengenai motivasi belajar siswa SD Negeri 3 Mangaran Kecamatan Mangaran Kabupaten Situbondo pada penelitian ini terdapat tiga temuan yaitu siswa yang memiliki motivasi belajar yang tinggi sebesar $36,4 \%$ denganjumlah siswa 8 , siswa yang memiliki motivasi belajar yang sedang sebesar 50\% dengan jumlah siswa 11, siswa yang memiliki motivasi belajar rendah sebesar 13,6\% dengan jumlah siswa 3 .

Data tentang motivasi belajar dalam penelitian ini diperoleh dengan skala yang dijawab oleh siswa SD Negeri 3 Mangaran. Berdasarkan Tabel 1maka dapat diketahui harga mean atau rata-rata skor sebesar 58,77, harga median atau nilai tengah sebesar 62 , hargamode atau nilai yang paling sering muncul adalah 68, standar deviasi sebesar 12,667, skor minimum adalah 37 dan skor maksimum adalah 78 .

c. Tabel Distribusi Frekuensi Motivasi Belajar

$$
\begin{aligned}
& \mathrm{K}=1+3,3 \log \mathrm{n} \\
& \mathrm{N}=\text { Jumlah responden yaitu } 22 \\
& \mathrm{~K}=1+3,3 \log 22 \\
& \mathrm{~K}=1+3,3 \times 1,342 \\
& \mathrm{~K}=1+4,42 \\
& \mathrm{~K}=5,42
\end{aligned}
$$

Sehingga jumlah kelas interval dibulatkan menjadi 5 kelas. Di bawah ini adalah tabel distribusi frekuensi untuk variabel motivasi belajar.

Tabel 2. Distribusi Frekuensi motivasi belajar

\begin{tabular}{|c|c|c|c|}
\hline No & Interval & Frekuensi & Presentase \% \\
\hline 1 & $37-45$ & 3 & 13,6 \\
\hline 2 & $46-54$ & 6 & 27,3 \\
\hline 3 & $55-63$ & 2 & 9,1 \\
\hline 4 & $64-72$ & 7 & 31,8 \\
\hline 5 & $73-81$ & 4 & 18,2 \\
\hline \multicolumn{2}{|r|}{} & 22 & 100 \\
\hline
\end{tabular}


Berdasarkan tabel di atas dapat diketahui distribusi frekuensi motivasi belajar tertinggi berada pada kelas interval nomor 4 yang mempunyai rentang 64-72 dengan jumlah sebanyak 7 siswa.

d. Grafik Distribusi Frekuensi Motivasi Belajar

Untuk visualisasi penyajian data tentang motivasi belajar siswa digunakan grafik batang agar lebih menarik dan komunikatif. Grafik distribusi frekuensi untuk variabel motivasi belajar dapat dilihat di bawah ini.

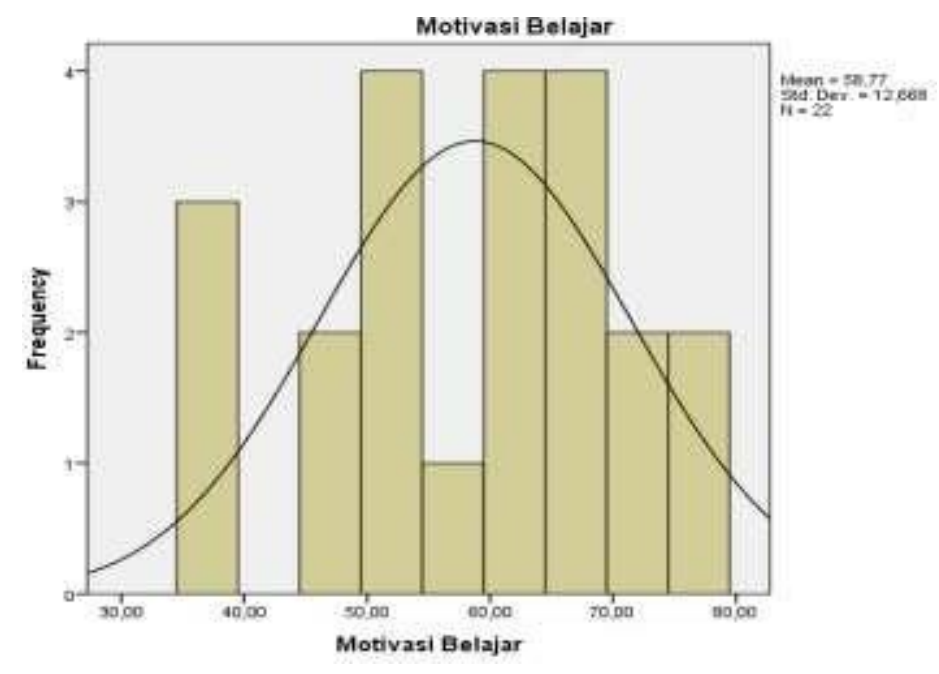

Grafik 2. Distribusi Frekuensi Motivasi Belajar

Distribusi data tentang kondisi ekonomi orang tua dapat dilihat pada Tabel dan Gambar di atas yaitu rentang skor 37-45 sebanyak 3 siswa, rentang 46-54 sebanyak 6 siswa, rentang 55-63 sebanyak 2 siswa, rentang skor 64-72 sebanyak 7 siswa, dan rentang 73-81 sebanyak 4 siswa.

Uji prasyarat analisis digunakan sebagai syarat untuk pengujian hipotesis menggunakan analisis regresi sederhana. Uji prasyarat yang digunakan dalam penelitian ini adalah uji normalitas dan uji linieritas. Untuk uji normalitas dilakuna dengan uji Kolmogrov Smirnov, untuk variabel kondisi ekonomiorang tua dengan signifikansi 0,2 dan variabel motivasi belajar sebesar 0,14. Kedua variabel tersebut memiliki signifikansi lebih dari 0,05 maka dapat dikatakan data dari masing-masing variabel berdistribusi normal. Untuk hasil uji linieritas diketahui nilai Sig.Deviation of Linieritysebesar 0,87> 0,05 maka dapat disimpulkan terdapat hubungan yang linier antara kondisi ekonomi orang tuasiswa dengan motivasi belajar.

Setelah dilakukan uji prasyarat, maka selanjutnya dilakukan pengujian hipotesis. Hipotesis adalah jawaban sementara dari rumusan masalah penelitian. Selanjutnya hipotesis diuji kebenarannya, apakah hipotesis dapat diterima atau ditolak. Hipotesis yang diajukan peneliti adalah terdapat pengaruh yang positif antara kondisi ekonomi orang tua terhadap motivasi belajar siswa. Hipotesis dalam penelitian ini diuji dengan menggunakan analisis regresi sederhana.

Pengujian hipotesis berdasarkan perhitungan SPSS 24, diperoleh besarnya nilai korelasi atau hubungan $(R)$ sebesar 0,597 atau 59,7\% yang berarti kondisi ekonomi orang tua memberikan pengaruh sebesar 59,7\% terhadap motivasi belajar. Nilai $F_{\text {hit }}$ sebsar 29,668 dengan tingkat signifikansi sebesar $0,000<0,05$. Nilai konstan (a) sebesar 13,144 sedangkan nilai Trus (b) sebesar 0,813 , sehingga persamaan regresinya adalah $Y=13,144$ $+0,813 \mathrm{X}$. Nilai $t_{\text {hit }}$ sebesar 5,477 nilai signifikansi 0,000. Karena signifikansi menunjukkan 
0,000 sehingga $0,000<0,05$, maka keputusannya adalah hipotesis penelitian diterima. Sementara itu kontribusi.

\section{KESIMPULAN}

1. Hasil penelitian menunjukan bahwa adanya pengaruh kondisi ekonomi orang tua terhadap motivasi belajar siswa SD Negeri 3 Mangaran Kecamatan Mangaran Kabupaten Situbondo sebesar 59,7\% dan 40,3\% dipengaruh oleh variabel lain.Kondisi ekonomi orang tua dalam hal ini terdapat tiga aspek yaitu penghasilan orang tua, fasilitas belajar, dan biaya sekolah. Hasil ini sejalan dengan penelitian sebelumnya yang dilakukan oleh Susanti dan Wahyudin (2017) bahwa terdapat pengaruh yang positif dan signifikan pengaruh kemampuan ekonomi orang tua tehadap motivasi belajar siswa. Teori human capital menyatakan bahwa untuk meningkatkan sumber daya manusia dapat dilakukan dengan pendidikan. Manusia harus terus-menerus mengembangkan dirinya untuk meningkatkan kualitas dirinya demi mengahadapi tantangan dan persaingan global. Kemampuan ekonomi berkaitan dengan kelangsungan proses pembelajaran secara tidak langsung tergadap motivasi belajar siswa. Kemampuan ekonomi orang tua mempunyai peranan penting dalam membentuk motivasi belajar siswa. Kemampuan ekonomi orang tua terhadap siswa akan membuat siswa akan termotivasi belajar yang dapat meningkatkan hasil belajarnya. Motivasi belajar merupakan rasa ketertarikan siswa pada hal-hal tertentu sehingga menimbulkan semangat dalam melakukan aktivitas tersebut.

2. Hasil ini sejalan dengan penelitian sebelumnya yang dilakukan oleh Susanti dan Wahyudin (2017) bahwa terdapat pengaruh yang positif dan signifikan pengaruh kemampuan ekonomi orang tua tehadap motivasi belajar siswa.Berdasarkan penelitian dan pembahasan di atas dapat disimpulkan bahwa ada pengaruh yang positif antara kondisi ekonomi orang tua dan motivasi belajar siswa SD Negeri 3 Mangaran Kecamatan Mangaran Kabupaten Situbondo

\section{ACKNOWLEDGMENT}

Penelitian ini didukung oleh Kementrian Riset, Teknologi, dan Pendidikan Tinggi Republik Indonesia melalui skema penelitian Simlitabmas Tahun 2019.

\section{BIBLIOGRAPHY}

Arikunto, Suharsimi. (2010). Prosedur Penelitian: Suatu Pendekatan Praktik. Jakarta: Rineka Cipta.

Arikunto, Suharsimi. (2011). Prosedur Penelitian: Suatu Pendekatan Praktik.Edisi Revisi VII. Jakarta: PT. Rineka Cipta.

Chotimah, L.N, Ani. H.M, \& Widodo, J. (2017). Pengaruh Status Sosial Ekonomi Orang Tua Terhadap Prestasi Belajar Siswa (Studi Kasus Siswa Kelas VIII SMP Negeri 1 Jember Tahun Ajaran 2016/2017). Jurnal Pendidikan Ekonomi: Jurnal Ilmiah Ilmu Pendidikan, IlmuEkonomi, dan Ilmu Sosial. Volume 11 Nomor 1. Halaman 75. Diakses dari https://jurnal.unej.ac.id/index.php/JPE/article/ view/5004.

Sardiman. (2012). Interaksi dan Motivasi Belajar Mengajar. Jakarta: Raja Grafindo Persada

Suryani, Nanik. (2006). Pengaruh Kondisi Sosial dan Ekonomi Orang Tua Terhadap Motivasi Melanjutkan Pendidikan ke Perguruan Tinggi. Jurnal Dinamika Pendidikan, Jurusan Manajemen Fakultas Ekonomi UNNES. Volume 1 Nomor 2. Halaman 191. Diakses dari https://journal.unnes.ac.id /nju/index.php/DP/article/view/476/433v 
Susanti.E danWahyudin.A. 2017. Pengaruh KemampuanEkonomi Orang Tua TerhadapHasil Belajar Melalui Fasilitas Belajar Di Rumah Dan MotivasiBelajarSebagai Intervening. Journal.Vol 6 No 2 (2017): Economic Education Analysis Journal 